\title{
統計解析に基づく静的支持力式の係数決定法について METHOD FOR DETERMINATION OF PARAMETERS OF PILE BEARING
CAPACITY FORMULA BASED ON STATISTICAL ANALYSIS
}

\author{
松尾稔* ·出村禧 典** . 菅井径世*** \\ By Minoru MATSUO, Yoshinori DEMURA and Michiyo SUGAI
}

\begin{abstract}
The first object of this paper is to modify the method, which was proposed by authors in the previous paper ${ }^{1}$, for determination of parameters of pile bearing capacity formula based on statistical analysis. Accordingly, a new method for estimation of skin friction of steel pipe piles driven into clay layers is proposed based on equation (1). The second object is to show the accuracy of the method. The results of statistical analysis with 68 in-situ loading tests which have been gathered and used in the previous paper are equal to the results of those with 112 tests which are gathered the present paper. Hence, it is seen that the reliability of the statistical analysis by using the data from a sample population of 68 in-situ loading tests is adequate. The new formula is compared with those estimated by the methods currently used in Japan and the engineering usefulness of the new method is emphasized.

Keywords : statistical analysis, bearing capacity, nonlinear least square, in-situ loading test
\end{abstract}

\section{1.はじめに}

著者らは，文献 1) において多数の載荷試験デー夕を 用い，統計解析に基づく静的支持力決定法を提案した. すなわち, 従来から実務設計に用いられている諸官公庁, 学協会の静的支持力式よりも，変動係数にして $10 \%$ 以 上精度の高い静的支持力式を提案したのである.しかし， 提案した支持力式は以下に示す 2 つ問題点を残してい た. 第 1 点は, 粘土層の. $N$ 值と周面摩擦力の関係に関 するものである. 提案した式によれば, $N$ 值 $=8$ のとき, 算定される単位面積当たりの支持力值が $9.6\left(\mathrm{tf} / \mathrm{m}^{2}\right)$ で あるのに，N 值=9になると $3.6\left(\mathrm{tf} / \mathrm{m}^{2}\right)$ になる. 第 2 点は, 支持力式決定法が統計解析に基づくことに起因す るもので, 用いるデー夕数によって解析解が異なってく る可能性を残した。本研究ノ一トは, 第 1 の問題点に対 する検討に加え，新たに収集した 45 個の実杭載荷試験 デー夕を利用し, デー夕数増加による解析解の違いや, 提案式の精度について検討した結果の報告である.

* 正会員 工博 名古屋大学教授 工学部地盤工学教室 ( (464-01 名古屋市千種区不老町)

** 正会員 工博 石川工業高等専門学校教授 土木工学科 ( ( 929-03 石川県河北群津幡町字北中条)

*** 学生会員 工修 名古屋大学大学院 工学研究科地盤工 学専攻 ( 4 464-01 名古屋市千種区不老町)

\section{2. 静的支持力式の分析および検討}

\section{（1）解析に用いたデータ}

種々の解析結果を示す前に，用いた載荷試験データに ついて触れておく，文献 1) で用いたデー夕に加え，新 たに収集したデー夕数は 45 であるが，このうち杭径 $800 \mathrm{~mm}$ 以上のデータは 1 個（杭径 $1500 \mathrm{~mm}$ ) のみであ る.したがって，文献 1) の3.（3），b）で述べたよ うに，本手法の適用限界を直径 $700 \mathrm{~mm}$ クラスまでの杭 に限ることとし, 文献 1) で用いた杭径 $800 \mathrm{~mm}$ 末満の データ 68 個と, 追加データ 44 個を用いて解析を行う.

図一1に解析に用いた杭の形状を度数分布の形で示 す、図からわかるように，追加したデー夕は，文献 1) で用いたデータと同種であり, 杭径, 杭長, 根入れ比 (支 持層への根入れ長さ $(L) /$ 杭径 $(D))$ において特異な データは追加していない.

図一2に地表面から杭を打ち止める支持層までに存在 する砂層および粘土層の平均 $N$ 值の杭周面積分布を示 す. 図一1の場合と同様, 文献 1) で用いたデー夕に比 ベ特異な地盤情報を含むデー夕は追加していない.

\section{（2）現行の支持力式の検討}

文献 1) にならい，代表的な実務設計用静的支持力式 の精度について検討する. 対象とした現行支持力式は, 


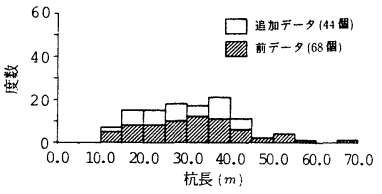

(a) 杭長

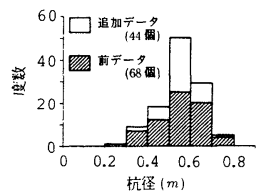

(b) 杭径

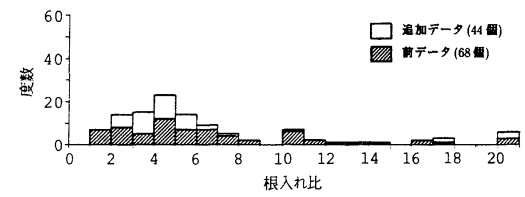

(c) 根入机此

図一1 解析に用いた杭の形状等（デー夕数 112 個）

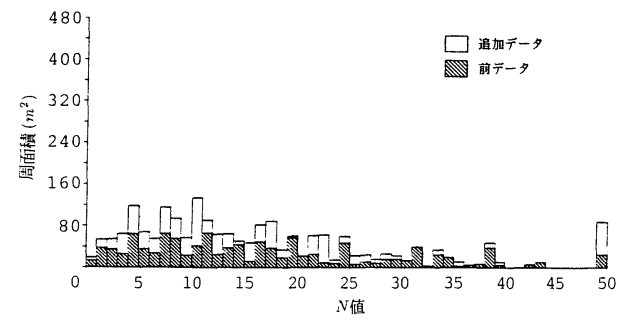

(a) 砂首

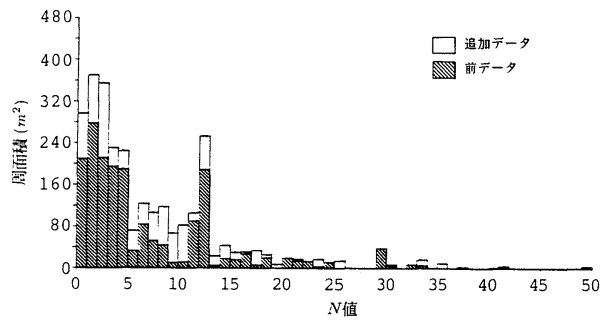

(b) 粘土層

図-2 周面摩擦にかかわる $N$ 值と杭周面積（デー夕数 112 個）

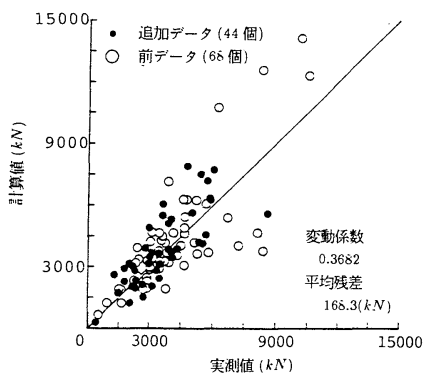

(a) 道路橋式

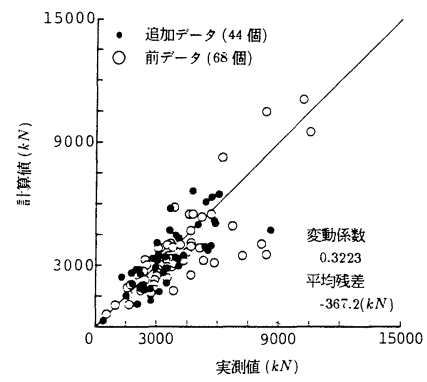

(b) 国铁式

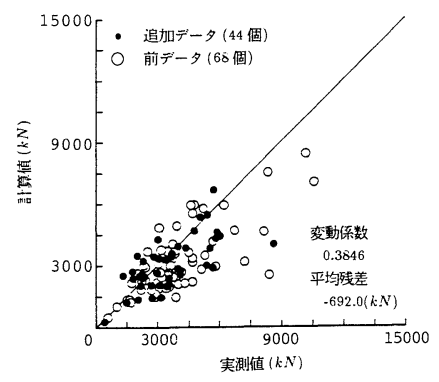

(c) 建筑学会式

図一3 実測値と現行支持力式による計算値の比較（デー夕数 112 個）

文献 1）上同様，「道路橋式」，「国鉄式」，「建築学会式」 の 3 つである. 図一3 は，112 個の全載荷試験デー夕を 用いて計算值と実测值を比較した結果である。いずれの 式も精度は比較的よい. 図中黒丸で示した追加デー夕 44 個をみても計算値は実測值とよく対応しており，こ れにより全体としての式の精度は若干ょくなっている. たたし, 図中に併記した残差の平均值 (平均残差) と変 動係数に着目しても, 文献 1) における解析と同様の結 果を示していることがわかる.

\section{（3）粘土層の $N$ 值による周面摩擦力推定に関する 検討}

文献 1）では，土丹や固結シルトなど過圧密度が非常 に高く $N$ 值の大きな層を, $N$ 值の小さな正規圧密粘土 層や若干過圧密された層とは別の性質の地盤と考えて取 り扱った。ところが, 文献 1) の式 (16) を用いると, 1. で述べたような矛盾が生じた。デー夕数が十分大き くなれば， $N$ 值によるのではなく地盤の種類別に層を
区分することが可能であるが，土丹や固結シルト層への 載荷試験データの収集は容易でない。この点を考慮し, 現行式にならって, 粘土層 $N$ 值の上限 $\left(N_{u p}\right)$ を定めて 支持力式を決定する手法を取ることとする2),3).すなわ ち, 粘土層においては, $N_{u p}$ 以上の $N$ 值は, $N=N_{u p}$ と して計算する. 提案する式を示すと以下のようである.

$$
\left.\begin{array}{r}
P_{u}=a_{1} \bar{N}_{p} A_{p}+a_{2} \sum N_{s} l_{s} U+a_{3} \sum N_{c} l_{c} U \\
N_{c} \leqq N_{u p}
\end{array}\right\} \ldots
$$

ここに, $A_{p}, U$ はそれぞれ杭の先端閉塞断面積および 杭周長を, $\bar{N}_{p}, N_{s}, N_{c}$ は支持層, 砂層および粘土層の 平均 $N$ 值を, $l_{s}, l_{c}$ は砂層および粘土層の層厚を, また, $a_{1}, a_{2}, a_{3}$ は文献 1 ) 々同様, 支持層, 砂層, 粘土層に 関する係数を表わす.

\section{(4) 提案法による数值計算例}

数值解析は, 文献 1) と同様, 次の項目ごとに順を追つ て進める.すなわち, a) $N_{u p}$ の決定， b) 根入れ比が先 端支持力の係数 $a_{1}$ に与える影響, c) 杭径が先端支持力 


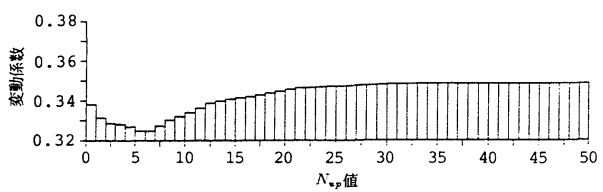

図一4 粘土層分類のための $\boldsymbol{N}_{u p}$ と式の精度（デー夕 68 個）

\section{表一1 係数 $\boldsymbol{a}_{1}, \boldsymbol{a}_{2}, \boldsymbol{a}_{3}$ の計算結果 $\left(N_{u p}=6\right)$}

\begin{tabular}{||c|c|c||c|c||}
\hline $\mathrm{a}_{1}$ & $\mathrm{a}_{2}$ & $\mathrm{a}_{3}$ & デー夕数 & 変動係数 \\
\hline \hline 31.18 & 0.155 & 1.068 & 68 & 0.3246 \\
\hline
\end{tabular}

表一3 根入れ比別の $\boldsymbol{a}_{1}$ の計算結果（デー夕数 68 個）

\begin{tabular}{||c||c||c|c||}
\hline 根入机比 & 係数 $\mathrm{a}_{1}$ & $\ddot{F}-$ 夕数 & 変動係数 \\
\hline \hline $0 \sim 1$ & - & 0 & - \\
\hline $1 \sim 2$ & 32.91 & 7 & 0.1256 \\
\hline $2 \sim 3$ & 15.74 & 8 & 0.3407 \\
\hline $3 \sim 4$ & 25.45 & 5 & 0.1033 \\
\hline $4 \sim 5$ & 33.26 & 12 & 0.2980 \\
\hline $5 \sim 6$ & 37.99 & 7 & 0.2349 \\
\hline $6 \sim 7$ & 37.79 & 7 & 0.3022 \\
\hline $7 \sim 8$ & 39.10 & 4 & 0.1026 \\
\hline $8 \sim 9$ & 97.23 & 2 & 0.2926 \\
\hline $9 \sim 10$ & - & 0 & - \\
\hline $10 \sim$ & 32.49 & 16 & 0.2869 \\
\hline
\end{tabular}

の係数 $a_{1}$ に与える影響， d) 実務設計に用いるための 各係数の有効な桁数についてである.さらに, 項目ごと に文献 1) で用いた 68 個のデータによる解析結果と, これに追加データ 44 個を加えた 112 個のデータによる 解析結果を比較, 検討する.

a) $N_{u p}$ の決定

$N_{u p}$ は, 文献 1) で $N_{L}$ を決定した手法と同様の方法 で決定する。すなわち，式（1）において $N_{u p}$ を 1 50 まで変えて支持力值計算を行い, それぞれに対して決定 された係数による式の精度を検討する手法である. 図一 4, 5 は, 各デー夕による計算結果である. 両図の横軸 は式（1）に代入した $N_{u p}$ 值である.また縦軸の変動 係数は，統計解析法により算定した各係数を式（1）に 適用して計算した支持力値と実測値を比較して求めたも のである. 両図とも $N_{u p}=6$ のときの変動係数が最小, 換言すると静的支持力式の精度が最もよくなる.した がって， $N_{u p}$ として 6 を採用する.

表一1，2に $N_{u p}=6$ とした場合の各係数の值と支持力 值に関する変動係数を示す。これらの表からわかるよう に, 非線形計画問題として定式化した提案法による各係 数值は, 現行の各静的支持力式に採用されている値と大 差がない。また，表一1，2 を比較しても，各係数值が ほぼ一致していることは特に注目すべきである.これは, デー夕数の違いにより解析解が変わらないことを意味し ており，ここで算定された係数值の信頼性の高さを示し ている. 表の計算結果から, 現行式よりも周面摩擦力を 若干小さく評価する方が一般に精度よく支持力を推定で きることがわかる.

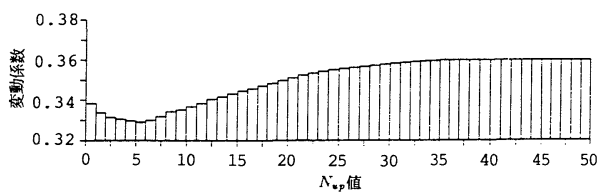

図一5 粘土層分類のための $\boldsymbol{N}_{u p}$ と式の精度（デー夕数 112 個）

表一2 根入れ比別の $\boldsymbol{a}_{1}, \boldsymbol{a}_{2}, \boldsymbol{a}_{3}$ の計算結果 $\left(N_{u p}=6\right)$

\begin{tabular}{||c|c|c||c|c||}
\hline $\mathrm{a}_{1}$ & $\mathrm{a}_{2}$ & $\mathrm{a}_{3}$ & $\vec{r}-$ 夕数 & 変動係数 \\
\hline \hline 29.14 & 0.159 & 1.111 & 112 & 0.3290 \\
\hline
\end{tabular}

表一4 根入れ比別の $\boldsymbol{a}_{1}$ の計算結果（デー夕数 112 個）

\begin{tabular}{||c||c||c|c||}
\hline 根入れ比 & 係数 $\mathrm{a}_{1}$ & デー夕数 & 変動係数 \\
\hline \hline $0 \sim 1$ & - & 0 & - \\
\hline $1 \sim 2$ & 32.07 & 7 & 0.1173 \\
\hline $2 \sim 3$ & 15.21 & 14 & 0.2670 \\
\hline $3 \sim 4$ & 22.71 & 15 & 0.2014 \\
\hline $4 \sim 5$ & 31.01 & 23 & 0.2754 \\
\hline $5 \sim 6$ & 30.07 & 14 & 0.2545 \\
\hline $6 \sim 7$ & 41.12 & 9 & 0.3452 \\
\hline $7 \sim 8$ & 37.25 & 5 & 0.0824 \\
\hline $8 \sim 9$ & 96.00 & 2 & 0.2910 \\
\hline $9 \sim 10$ & - & 0 & - \\
\hline $10 \sim$ & 33.52 & 23 & 0.2990 \\
\hline
\end{tabular}

次に，表一1，2に基づき，デー夕数 68 個の場合には $a_{2}, a_{3}$ をそれぞれ $0.16,1.07$,デー夕数 112 個の場合 には $a_{2}, a_{3}$ をそれぞれ $0.16,1.11$ と固定したうえで, 根入れ比や杭径に影響されると考えられる $a_{1}$ の検討を さらに深める.

b) 根入れ比が先端支持力の係数 $a_{1}$ に与える影響

表一3，4に，根入れ比別にまとめたデー夕から計算 した $a_{1}$ の值，計算に用いたデ一夕数，支持力值に関す る変動係数を示す. 文献 1 ), 3. ( 3 ), b), (2)で述べた ように, 根入れ比 2 以下の場合を除き, 両表とも一般に 根入れ比が小さいときに $a_{1}$ 值が小さい. したがって, 係数 $a_{1}$ に関しては根入れ比で次のように区分けして検 討を進める. すなわち，デー夕数 68 個の場合は文献 1) と同様, 2 以下, $2 \sim 3,3 \sim 4,4$ 以上の 4 つの範囲, デー 夕数 112 個の場合は, 2 以下, 2 3, 3 4, 4 6, 6 以 上の 5 つの範囲に分ける. 後者の場合には, データ数の 増加により分ける範囲を増やし, 支持力式の精度を高め る.

c) 杭径が先端支持力の係数 $a_{1}$ に与える影響

表一 $5 ， 6$ は，b）で決定したように根入れ比で区分け し, さらに各杭径別に求めた $a_{1}$ の值, デー夕数, 支持 力值に関する変動係数を示している.これらの結果によ れば，杭径 250.0〜355.6 mm のものは閉塞効果が十分 に発揮されると考えられ，比較的大きな係数值を示して いる.しかし, デー夕数の少ないこと, および小口径杭 の取り扱いが通常は若干粗雑になる実務上の安全性を考 慮して, 他の杭と同じ係数を用いることにする. また, 両表からはデー夕数の違いによる係数值の大きな違いは 
表一5 杭径別の $\boldsymbol{a}_{1}$ の計算結果（デー夕数 68 個）

\begin{tabular}{|c|c|c|c|c|c|c|c|c|c|c|c|}
\hline \multirow{3}{*}{\multicolumn{2}{|c|}{$\begin{array}{l}\text { 杭径 } \\
\text { 根入れ比 }\end{array}$}} & \multicolumn{2}{|c|}{$318.5 \sim 355.6$} & \multicolumn{2}{|c|}{$400.0 \sim 485.0$} & \multicolumn{2}{|c|}{$500.0 \sim 508.0$} & \multicolumn{2}{|c|}{$600.0-660.4$} & \multicolumn{2}{|c|}{$700.0 \sim 711.2$} \\
\hline & & 係数 $\mathrm{a}_{1}$ & $\bar{T}-$ 夕数 & 倸数 $\mathrm{a}_{1}$ & $\vec{r}-$ 夕数 & 倸数 $\mathrm{a}_{1}$ & F゙ー夕数 & 係数 $\mathrm{a}_{1}$ & $\vec{T}-$ 夕数 & 係数 $\mathrm{a}_{1}$ & $\widetilde{T}-$ 夕数 \\
\hline & & \multicolumn{2}{|c|}{ 変動俰数 } & \multicolumn{2}{|c|}{ 変動係数 } & \multicolumn{2}{|c|}{ 変動係数 } & \multicolumn{2}{|c|}{ 変動係数 } & \multicolumn{2}{|c|}{ 変動係数 } \\
\hline \multirow{2}{*}{\multicolumn{2}{|c|}{$\sim$}} & - & 0 & 29.32 & 3 & 33.11 & 3 & 45.72 & 1 & - & 0 \\
\hline & & & & \multicolumn{2}{|c|}{0.2013} & \multicolumn{2}{|c|}{0.0586} & \multicolumn{2}{|c|}{-} & \multicolumn{2}{|c|}{-} \\
\hline \multirow[t]{2}{*}{2} & \multirow[t]{2}{*}{$\sim$} & - & 0 & 22.37 & 2 & 14.59 & 3 & 15.51 & 3 & - & 0 \\
\hline & & & & \multicolumn{2}{|c|}{0.1266} & \multicolumn{2}{|c|}{0.3000} & \multicolumn{2}{|c|}{0.4673} & \multicolumn{2}{|c|}{-} \\
\hline \multirow[t]{2}{*}{3} & \multirow[b]{2}{*}{4} & - & 0 & 24.15 & 1 & 31.24 & 1 & 18.03 & 1 & 27.90 & 2 \\
\hline & & \multicolumn{2}{|c|}{-} & \multicolumn{2}{|c|}{-1} & \multicolumn{2}{|c|}{-} & & & \multicolumn{2}{|c|}{0.0428} \\
\hline \multirow[t]{2}{*}{4} & $\sim$ & 50.88 & 7 & 29.26 & 6 & 39.51 & 18 & 35.78 & 15 & 30.64 & 2 \\
\hline & & \multicolumn{2}{|c|}{0.2121} & \multicolumn{2}{|c|}{0.1385} & \multicolumn{2}{|c|}{0.1943} & \multicolumn{2}{|c|}{0.3695} & \multicolumn{2}{|c|}{0.2974} \\
\hline
\end{tabular}

表一 6 杭径別の $\boldsymbol{a}_{1}$ の計算結果（デー夕数 112 個）

\begin{tabular}{|c|c|c|c|c|c|c|c|c|c|c|c|}
\hline \multirow{3}{*}{\multicolumn{2}{|c|}{$\begin{array}{l}\text { 杭径 } \\
\text { 根入れ比 }\end{array}$}} & \multicolumn{2}{|c|}{$250.0 \sim 355.6$} & \multicolumn{2}{|c|}{$400.0 \sim 485.0$} & \multicolumn{2}{|c|}{$500.0 \sim 508.0$} & \multicolumn{2}{|c|}{$600.0-660.4$} & \multicolumn{2}{|c|}{$700.0 \sim 750.0$} \\
\hline & & 倸数 $\mathrm{a}_{1}$ & デー夕数 & 係数 $\mathrm{a}_{1}$ & $\vec{T}-$ 夕数 & 保数 $\mathrm{a}_{1}$ & デー夕数 & 係数 $\mathrm{a}_{1}$ & デー夕数 & 係数 $\mathrm{a}_{1}$ & デー夕数 \\
\hline & & \multicolumn{2}{|c|}{ 変動係数 } & \multicolumn{2}{|c|}{ 変動係数 } & \multicolumn{2}{|c|}{ 変動係数 } & \multicolumn{2}{|c|}{ 変動係数 } & \multicolumn{2}{|c|}{ 変動係数 } \\
\hline \multirow{2}{*}{\multicolumn{2}{|c|}{-}} & - & 0 & 28.58 & 3 & 32.31 & 3 & 44.15 & 1 & - & 0 \\
\hline & & \multicolumn{2}{|c|}{$=$} & \multicolumn{2}{|c|}{0.1835} & \multicolumn{2}{|c|}{0.0591} & \multicolumn{2}{|c|}{ - } & \multicolumn{2}{|c|}{-} \\
\hline \multirow[t]{2}{*}{2} & \multirow[b]{2}{*}{3} & - & 0 & 16.38 & 3 & 11.94 & 5 & 16.23 & 6 & - & 0 \\
\hline & & & & \multicolumn{2}{|c|}{0.1784} & \multicolumn{2}{|c|}{0.2478} & \multicolumn{2}{|c|}{0.2991} & \multicolumn{2}{|c|}{-} \\
\hline \multirow[t]{2}{*}{3} & - & - & 0 & 14.89 & 2 & 29.43 & 7 & 15.81 & 4 & 27.25 & 2 \\
\hline & 4 & & & \multicolumn{2}{|c|}{0.3939} & \multicolumn{2}{|c|}{0.1919} & \multicolumn{2}{|c|}{0.1078} & \multicolumn{2}{|c|}{0.0355} \\
\hline \multirow[t]{2}{*}{4} & $\sim$ & 41.86 & 4 & 25.41 & 5 & 35.78 & 20 & 33.25 & 6 & 22.20 & 2 \\
\hline & 6 & \multicolumn{2}{|c|}{0.4345} & \multicolumn{2}{|c|}{0.1289} & \multicolumn{2}{|c|}{0.1907} & \multicolumn{2}{|c|}{0.4045} & \multicolumn{2}{|c|}{0.1755} \\
\hline \multirow[t]{2}{*}{6} & $\sim$ & 50.99 & 6 & 36.38 & 5 & 43.23 & 15 & 33.48 & 12 & 41.99 & 1 \\
\hline & & \multicolumn{2}{|c|}{0.3048} & & 1623 & & 228 & & 3682 & & \\
\hline
\end{tabular}

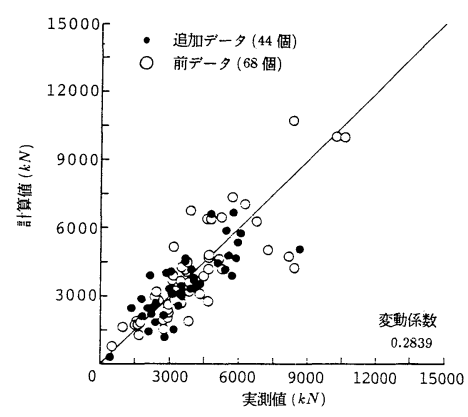

図一6 実測値と提案式による計算值の比較

(デー夕数 112 個)

みられない。

d）実務設計に用いるための各係数の有効な桁数

表一7は，以上の解析に基づき，全載荷試験デー夕 112 個を用いて求めた $a_{1}$ 值とそのときのデー夕数，支 持力值に関する変動係数を示したものである.表からは, 根入れが十分であれば一般に現行支持力式の場合よりも 若干大きめの先端支持力值が期待できることがわかる. さらに，図一6は，これらを式（1）に適用して求めた 計算値と載荷試験における実測值を比較したものであ る. 当然のこととはいえ, 提案法では図一3に示したい ずれの支持力式よりも高い精度の推定值を与えている.

なお，実務式として用いる場合には，工学的に有効な 精度を保持しつつ，各係数值はできるだけ簡単な方がよ い.この観点から表一7の值を再整理したものが表一8 である. 式の精度は, 同じく表中の変動係数（0.284） に示したように図6と比較してほとんど落ちず，実用
表一 8 実用式の係数値

\begin{tabular}{|c|c|c|c|c|}
\hline \multicolumn{2}{|c|}{ 根入れ比 } & 係数 $\mathrm{a}_{1}$ & & 係数 \\
\hline & $\sim$ & 32.0 & $a_{2}$ & 0.16 \\
\hline 2 & - & 15.0 & $a_{3}$ & 1.10 \\
\hline 3 & $\sim$ & 23.0 & $\bar{r}-$ 数 & 112 \\
\hline 4 & $\sim$ & 31.0 & 変動倸数 & 0.2840 \\
\hline 6 & - & 38.0 & & \\
\hline
\end{tabular}

的にはこれで十分である. 新しく提案する実用式は, 式 (1) に表一8の係数值を適用したものとする.

\section{3.おわりに}

本研究ノ一トは，文献 1) において著者らが提案した 統計解析に基づく静的支持力式決定法に基づき，新たに 44 個の載荷試験データを追加して静的支持力式を決定 し，さらにその信頼性や精度について検討を加えたもの である。主な結果は，以下のとおりである。

（1）粘土層の $N$ 值と単位面積当たりの周面摩擦力 值の関係を新たに提案した。

（2）文献1）で用いたデータによる解析結果と, 追 加データによる解析結果を比較することにより提案した 支持力式の信頼性を検討した。

\section{参 考 文 献}

1）松尾 稔 - 菅井径世 - 金 聲漢：鋼管杭の極限支持力推 定法に関する研究，土木学会論文集，第 406 号 / III-11, pp. 253 262，1989 年 6 月.

2）日本道路協会：道路橋示方書・同解説，IV下部構造編， 1987.5.

3）土木学会編：国鉄建造物設計標準解説（基礎構造物, 抗 土圧構造物)，1986.

(1990.6.6 • 受付) 